\title{
Identification of Newer Antimicrobial Agents: A Study of Invitro Antibacterial and Antifungal Activities of Leaf extracts of Medicinal Plant Aerva lanata (L.) Juss. ex Schult
}

\author{
Madhusudhan Kairamkonda ${ }^{1}$, Vikram Godishala ${ }^{2}$, Venkataramana Kandi ${ }^{3, *}$ \\ ${ }^{1}$ Department of Biology, Rajiv Gandhi University of Knowledge Technologies, Basar, Telangana, India \\ ${ }^{2}$ Department of Biotechnology, Vaagdevi Degree and PG College, Warangal, Telangana India \\ ${ }^{3}$ Department of Microbiology, Prathima Institute of Medical Sciences, Karimnagar, Telangana, India \\ *Corresponding author: ramana_20021@rediffmail.com
}

\begin{abstract}
In the era of presence and spread of infectious diseases caused by microorganisms demonstrating resistance against most antimicrobial agents routinely used in the treatment, there is a serious need of search for potential agents which can be used as antimicrobials. The plant extracts of Aerva lanata were collected and processed using standard procedures. Whatman filter papers were then impregnated with varied concentrations of plant extract and antimicrobial susceptibility testing was performed using Kirby-Bauer disk diffusion method for bacteria. The standard disk diffusion method was used to test antifungal drugs against yeasts, and non-dermatophyte filamentous fungal isolates.The ethanolic extract at a concentration of $600 \mu \mathrm{g} / \mathrm{mL}$ and $900 \mu \mathrm{g} / \mathrm{mL}$ showed increased antibacterial activities against Esherichia coli as compared to the standard drug tested at similar concentrations. The chloroform extracts and the ethanol extract revealed increased antibacterial activity against Klebsiella pneumoniae. The chloroform solvent extract showed similar antifungal activities as the standard drug against Candida albicans, and the $\mathrm{H}_{2} \mathrm{O}$ extract showed greater antifungal activity against Drechslera halodes as compared to the control drug tested. Antibacterial and antifungal properties of leaf extracts of Aerva lanata plant in comparison with the control drugs revealed either similar or increased activities signifying their potential for future candidates as antimicrobial agents.
\end{abstract}

Keywords: Aerva lanata, Infectious diseases, Antibacterial and antifungal properties of Aerva lanata, Antimicrobial resistance

Cite This Article: Madhusudhan Kairamkonda, Vikram Godishala, and Venkataramana Kandi, "Identification of Newer Antimicrobial Agents: A Study of Invitro Antibacterial and Antifungal Activities of Leaf extracts of Medicinal Plant Aerva lanata (L.) Juss. ex Schult.” American Journal of Microbiological Research, vol. 5, no. 3 (2017): 66-70. doi: 10.12691/ajmr-5-3-3.

\section{Introduction}

Emergence and spread of microbial drug-resistance has limited the choice of antimicrobial agents and has been responsible for severe morbidity and mortality [1]. Bacteria, fungi, parasites and viruses cause many infections in both human and animals which are now difficult to treat owing to their resistance to most of the available antimicrobial drugs. Ability of some microorganisms to change their antigenic structure each time they result in an infection has been responsible for non-availability of a standard vaccine for many microbial infections (Human Immunodeficiency Virus (HIV), Hepatitis C virus (HCV), Influenza virus and others [2]. Significant time taken for the synthesis and availability of an approved allopathic drug in the market should be considered as a cause for serious concern in health care settings. Research is rigorously on for finding alternatives to allopathic antimicrobial agents, which include preparation of synthetic antibiotics, evaluating the nanoparticles for their utility in treating infections and analysing the activities of various plant extracts for their medicinal properties [3,4,5].

Aerva lanata (L.) Juss. ex. Schult. is a medicinal plant belonging to the family Amaranthaceae. It is commonly called as a mountain knot grass, which grows all along the plains of India. Aerva lanata is a perennial herbaceous weed growing up to 2 meters ( $30 \mathrm{~cm}$ to $2 \mathrm{~m}$ ) tall which is present through the warmer geographical plains of India including the states of Telangana, Andhrapradesh, Tamilnadu, Karnataka, and Kerala. Other countries where this plant grows include Srilanka, Arabian regions, Egypt, African regions, Java, Philippines, and Australia [6,7].

Previous studies have evaluated anti-oxidant properties, nephroprotective activities, hepatoprotective properties, anti lithiatic activities (increased urinary excretion of 
calcium, oxalate and uric acid crystals, antidiabetic/hypoglycaemic activities, anti-hyperlipidemic activities and anti-cancer properties of Aerva lanata. Few other studies have highlighted the pharmacological applications of Aerva lanata plant extracts which included its diuretic properties, anti-inflammatory activities, cytotoxic nature, and antimicrobial properties [7,8,9,10,11].

It has been observed that the plant extracts of Aerva lanata were traditionally used to treat common ailments like head ache, jaundice, cholera, reduce bleeding during normal deliveries, treating burns wounds and skin conditions, urinary and gall stones, nasal bleeding, cough and bronchitis, diarrhoea and dysentery, rheumatoid arthritis, fractures, and scorpion stings and snake bites $[12,13]$. Only few studies are available in literature, which have evaluated the antimicrobial properties of various extracts of this medicinal plant [14-19].

The present study evaluates the in-vitro activities of various plant extracts (leaf) of Aerva lanata against both Gram positive and Gram negative bacteria (Escherichia coli, Proteus vulgaris, Enterobacter aerogenes, Klebsiella pneumoniae, Bacillus subtilis, Bacillus megaterium, Bacillus pumilus, Staphylococcus aureus, Streptococcus pyogenes, and Enterococcus faecalis) and fungi (Candida albicans, Fusarium oxysporum, Drechslera halodes and Colletotrichum falcatum).

\section{Materials and Methods}

The Aerva lanata plant was collected from the botanical garden, Kakatiya University, Warangal, Telangana, India.

\subsection{Phyto-chemical Extraction}

The leaves collected from the plant were allowed to dry in shade and was later ground to powder by mortar and chisel manually. The plant powder was then defatted with petroleum ether at $40^{\circ}-60^{\circ} \mathrm{C}$ for 2 hours. The defatted powder was then processed for extraction in Soxhelt extractor using various solvents like benzene (A), water (B), chloroform (C), Acetone (D) and 80\% ethanol (E). Various solvent extracts were then subjected to vacuum distillation under reduced pressure using a rotavapour to produce a semi-solid residue. The extracts were purified by distilled water and overnight treatment with sodium sulphite to remove moisture. The standard antiobiotic was used as a control for bacteria (Streptomycin) and fungi (Itraconazole).

Using a whatman filter paper $1,6 \mathrm{~mm}$ disks were prepared consisting of different plant extract concentrations. The plant extract concentrations prepared included $600 \mu \mathrm{g} / \mathrm{mL}$ and $900 \mu \mathrm{g} / \mathrm{mL}$ for antibacterial activity; $300 \mu \mathrm{g} / \mathrm{mL}, 600 \mu \mathrm{g} / \mathrm{mL}, 900 \mu \mathrm{g} / \mathrm{mL}$ and 1200 $\mu \mathrm{g} / \mathrm{mL}$ for antifungal activities. The antibacterial activity of various preparations of Aerva lanata plant extract was studied using Kirby-Bauer disc diffusion method. The microorganisms tested included were both gram positive (Bacillus subtilis, Bacillus megaterium, Bacillus pumilus, Staphylococcus aureus, Streptococcus pyogenes, Enterococcus faecalis) and gram negative bacteria (Escherichia coli, Proteus vulgaris, Enterobacter aerogenes, Klebsiella pneumoniae). The control bacterial strains used included Staphylococcus aureus ATCC 25923 , Pseudomonas aeruginosa ATCC 27853, E coli ATCC 25922.

\subsection{Antimicrobial Susceptibility Testing}

Two-three pure and isolated colonies from overnight bacterial growth was inoculated in to peptone water/sterile saline and later incubated at $37^{\circ} \mathrm{C}$ for $1-2$ hours. The test tube with growth is then adjusted to match the turbidity equal to and not more than 0.5 Mac Farland standards. Mac Farlands is a standard for measuring turbidity manually by comparing and adjusting the culture turbidity with a solution prepared by mixing $0.05 \mathrm{~mL}$ of $1 \%$ barium chloride and $9.95 \mathrm{~mL}$ of $1 \%$ sulphuric acid. The test organisms is then inoculated in to Mueller-Hinton agar (MHA) as lawn culture/carpet culture with the help of sterile cotton swabs, later various antimicrobial impregnated filter paper disks were applied with the help of sterile forceps. The plates were then incubated overnight at $37^{\circ} \mathrm{C}$. The sensitivity of the test microorganism is observed as absence of growth around the disks termed as zone of inhibition which is measured in millimetres and resistance of the bacteria towards the antimicrobial agent is indicated by the presence of growth towards the edge of the disk. The interpretation of results was done according to clinical laboratory standards institute (CLSI) guidelines [20].

The disk diffusion susceptibility testing for fungi was performed according to CLSI guidelines. The fungal inoculums was prepared by microdilution method to yield a fungal count of $10^{4} \mathrm{CFU} / \mathrm{mL}$. Using a whatman filter paper 1 , disks of $6 \mathrm{~mm}$ were prepared by impregnating the solvent plant extract. The disks were then allowed to dry in dark. Muller-Hinton agar (MHA) was then inoculated as lawn culture with turbidity adjusted (0.5 Macfarlands equalling count of $10^{4} \mathrm{CFU} / \mathrm{mL}$ ) fungal broth using a sterile cotton swab. The plant extract impregnated antifungal disks were then dispensed onto the surface of the inoculated agar plates. The plates were incubated at $28^{\circ} \mathrm{C}$, and the inhibition zone diameters (IZDs) were measured in millimetres (mm) after 5 days [21,22].

\section{Results}

The ethanolic extract (E) at a concentration of $600 \mu \mathrm{g} /$ $\mathrm{mL}$ and $900 \mu \mathrm{g} / \mathrm{ml}$ showed increased zones of inhibition against Esherichia coli as compared to the standard drug tested at similar concentrations. The chloroform extracts (C) and the ethanol extract (E) revealed increased antibacterial activity against Klebsiella pneumoniae. The details of antimicrobial activities of Aerva lanata plant extracts against various bacteria at different concentrations is shown in Table 1.

The chloroform solvent extract (C) showed similar antifungal activities as the standard drug against Candida albicans. The H2O (B) extract showed greater antifungal activity against Drechslera halodes as compared to the control drug tested. The anti-fungal activities of various solvent plant extracts of Aerva lanata at varied concentrations against different fungi (yeasts and moulds) are shown in Table 2. 
Table 1. Antibacterial susceptibility profile of various solvent extracts of Aerva lanata at different concentrations

\begin{tabular}{|c|c|c|c|c|c|c|}
\hline $\begin{array}{l}\text { Name of the Solvent } \\
\text { Extract }\end{array}$ & $\begin{array}{l}\text { Concentration of the } \\
\text { Extract }(\mu \mathrm{g} / \mathrm{ml})\end{array}$ & \multicolumn{5}{|c|}{ Antibacterial Susceptibility Profile Interpreted as Zone of inhibition (mm) } \\
\hline \multicolumn{2}{|c|}{ Microorganism Tested } & $\begin{array}{l}\text { Escherichia } \\
\text { coli }\end{array}$ & $\begin{array}{l}\text { Proteus } \\
\text { vulgaris }\end{array}$ & $\begin{array}{c}\text { Klebsiella } \\
\text { pneumoniae }\end{array}$ & $\begin{array}{c}\text { Enterobacter } \\
\text { aerogenes }\end{array}$ & Bacillus subtilis \\
\hline \multirow{2}{*}{ Benzene (A) } & 600 & 2.6 & 4.2 & 3.24 & NA & 5.3 \\
\hline & 900 & 4.8 & 8.02 & 6.34 & NA & 10.65 \\
\hline \multirow{2}{*}{$\begin{array}{l}\text { Water }\left(\mathrm{H}_{2} \mathrm{O}\right) \\
\text { (B) }\end{array}$} & 600 & 2 & 5.02 & 2.89 & 3.25 & 2.08 \\
\hline & 900 & 4.01 & 10.25 & 6.24 & 6.8 & 4.16 \\
\hline \multirow{2}{*}{$\begin{array}{c}\text { Chloroform }\left(\mathrm{CCl}_{2}\right) \\
\text { (C) }\end{array}$} & 600 & NA & 2 & 5.48 & 4.24 & 4.28 \\
\hline & 900 & NA & 4.25 & 10.09 & 8.9 & 8.9 \\
\hline \multirow{2}{*}{ Acetone (D) } & 600 & 1.25 & 4.2 & 2.04 & 2 & 2.5 \\
\hline & 900 & 3.49 & 8.09 & 4.25 & 4.02 & 4.25 \\
\hline \multirow{2}{*}{ 80\%Ethanol (E) } & 600 & 7.02 & 4.02 & 8.82 & 4.25 & 9.02 \\
\hline & 900 & 14.05 & 8.04 & 14.02 & 8.08 & 12.08 \\
\hline \multirow{2}{*}{$\begin{array}{l}\text { Standard Antibiotic } \\
\text { (Streptomycin) }\end{array}$} & 600 & 3.06 & 8.9 & 3.24 & 4.47 & 8.44 \\
\hline & 900 & 6.14 & 16.09 & 6.54 & 8.76 & 16.22 \\
\hline $\begin{array}{c}\begin{array}{c}\text { Name of the Solvent } \\
\text { Extract }\end{array} \\
\end{array}$ & $\begin{array}{c}\text { Concentration of the } \\
\text { Extract }(\mu \mathrm{g} / \mathrm{ml})\end{array}$ & \multicolumn{5}{|c|}{ Antibacterial Susceptibility Profile Interpreted as Zone of inhibition (mm) } \\
\hline \multicolumn{2}{|c|}{ Microorganism Tested } & $\begin{array}{c}\text { Bacillus } \\
\text { megaterium }\end{array}$ & $\begin{array}{l}\text { Bacillus } \\
\text { pumilus }\end{array}$ & $\begin{array}{l}\text { Staphylococcus } \\
\text { aureus }\end{array}$ & $\begin{array}{c}\text { Streptococcus } \\
\text { pyogenes }\end{array}$ & $\begin{array}{l}\text { Enterococcus } \\
\text { faecalis }\end{array}$ \\
\hline \multirow{2}{*}{ Benzene (A) } & 600 & 4.48 & 5.02 & 3.41 & 5.3 & 2.65 \\
\hline & 900 & 8.98 & 10.71 & 6.48 & 10.2 & 4.29 \\
\hline \multirow{2}{*}{$\begin{array}{l}\text { Water }\left(\mathrm{H}_{2} \mathrm{O}\right) \\
\text { (B) }\end{array}$} & 600 & 6.25 & NA & 4.25 & 6.25 & 4.28 \\
\hline & 900 & 12.09 & NA & 8 & 13.08 & 5.02 \\
\hline \multirow{2}{*}{$\begin{array}{l}\text { Chloroform }\left(\mathrm{CCl}_{2}\right) \\
\text { (C) }\end{array}$} & 600 & 4.26 & 5.25 & 3 & 2.08 & 5.25 \\
\hline & 900 & 8.19 & 10.53 & 6.25 & 4.19 & 10.5 \\
\hline \multirow{2}{*}{ Acetone (D) } & 600 & 4.2 & 3.2 & 1.55 & 3.25 & 1.02 \\
\hline & 900 & 8.4 & 6.8 & 3.25 & 6.84 & 2.48 \\
\hline \multirow{2}{*}{ 80\%Ethanol (E) } & 600 & 6.3 & 2.01 & 6.5 & 3.27 & 4.91 \\
\hline & 900 & 12.01 & 4.28 & 12.01 & 6.25 & 9.01 \\
\hline \multirow{2}{*}{$\begin{array}{l}\text { Standard Antibiotic } \\
\text { (Streptomycin) }\end{array}$} & 600 & 6.23 & 7.25 & 10.34 & 8.19 & 12.82 \\
\hline & 900 & 12.8 & 14.5 & 20.01 & 16.47 & 20.34 \\
\hline
\end{tabular}

Table 2. Antifungal susceptibility profile of various solvent extracts of Aerva lanata at different concentrations

\begin{tabular}{|c|c|c|c|c|c|}
\hline Name of the Solvent Extract & $\begin{array}{l}\text { Concentration of the } \\
\text { Extract }(\mu \mathrm{g} / \mathrm{ml})\end{array}$ & \multicolumn{4}{|c|}{ Antifungal Susceptibility Profile Interpreted as Zone of inhibition (mm) } \\
\hline \multicolumn{2}{|c|}{ Microorganism Tested } & $\begin{array}{l}\text { Candida } \\
\text { albicans }\end{array}$ & $\begin{array}{c}\text { Fusarium } \\
\text { oxysporum }\end{array}$ & $\begin{array}{c}\text { Drechslera } \\
\text { halodes }\end{array}$ & $\begin{array}{c}\text { Colletotrichum } \\
\text { falcatum }\end{array}$ \\
\hline \multirow{4}{*}{$\begin{array}{l}\text { Benzene } \\
\text { (A) }\end{array}$} & 300 & 2.25 & 4.20 & 5.02 & 3.24 \\
\hline & 600 & 4.50 & 8.56 & 7.68 & 5.56 \\
\hline & 900 & 9.60 & 16.95 & 14.25 & 13.56 \\
\hline & 1200 & 18.25 & 28.06 & 26.80 & 25.92 \\
\hline \multirow{4}{*}{$\begin{array}{l}\text { Water }\left(\mathrm{H}_{2} \mathrm{O}\right) \\
(\mathrm{B})\end{array}$} & 300 & 3.02 & 3.56 & 4.56 & 5.62 \\
\hline & 600 & 5.84 & 6.15 & 8.12 & 9.76 \\
\hline & 900 & 10.08 & 14.24 & 15.60 & 19.40 \\
\hline & 1200 & 19.65 & 29.45 & 31.26 & 33.81 \\
\hline \multirow{4}{*}{ Chloroform $\left(\mathrm{CCl}_{2}\right)(\mathrm{C})$} & 300 & 2.76 & NA & 3.80 & 4.08 \\
\hline & 600 & 5.62 & NA & 7.56 & 8.62 \\
\hline & 900 & 11.04 & NA & 15.01 & 17.02 \\
\hline & 1200 & 23.25 & NA & 28.76 & 31.80 \\
\hline \multirow{4}{*}{$\begin{array}{l}\text { Acetone } \\
\text { (D) }\end{array}$} & 300 & NA & 2.48 & 3.25 & 4.49 \\
\hline & 600 & NA & 4.92 & 6.02 & 7.60 \\
\hline & 900 & NA & 12.08 & 14.56 & 16.81 \\
\hline & 1200 & NA & 19.84 & 28.65 & 32.50 \\
\hline \multirow{4}{*}{$\begin{array}{l}80 \% \text { Ethanol } \\
\text { (E) }\end{array}$} & 300 & 2.01 & 3.08 & 2.89 & 3.25 \\
\hline & 600 & 4.89 & 6.25 & 5.76 & 6.50 \\
\hline & 900 & 9.56 & 13.56 & 11.56 & 13.76 \\
\hline & 1200 & 17.25 & 25.80 & 23.25 & 26.45 \\
\hline \multirow{4}{*}{$\begin{array}{l}\text { Standard Antibiotic } \\
\text { (Itraconazole) }\end{array}$} & 300 & 2.67 & 5.46 & 3.56 & 4.45 \\
\hline & 600 & 5.35 & 10.80 & 7.56 & 9.34 \\
\hline & 900 & 12.01 & 20.03 & 14.76 & 18.26 \\
\hline & 1200 & 23.04 & 34.35 & 27.36 & 33.75 \\
\hline
\end{tabular}




\section{Discussion}

Aerva lanata is also called as Aerva elegans, Illecebrum lanatum and Achyranthes lanata and is commonly known as mountain knot grass. There are about 28 identified species of Aerva genus, among which only A persica, $A$ lanata and $A$ javanica were known to possess medicinal properties [24].

This medicinal plant is locally named as Pindidonda in Telugu, Chaya, Gorakh buti, Gorakh ganja, kapurijad, Khari and Khali in Hindi, Ciru-pulai and Ulinai in Tamil, Kapurmadhuri in Marathi, Bili Himdi Soppu in Kannada, Cherula in Malayalam, Bhuyi in Rajasthan, Chaya in Bengali, Bhui and Jari in Sindhi, Polpala in Sinhalese, Kinongo in Swahili and Bhadra, Ashmahabhedah, Gorakshaganja, Pashanabheda and Shatakabhedi in Sanskrit [25]. Aerva lanata has been traditionally used as a medicine for treating various ailments. Increased antibacterial activities of the Aerva lanata plant extracts were observed against few potential bacterial pathogens as compared to the standard drug tested highlighting their use in treating the infections in human. Antifungal properties of Aerva lanata plant extracts were compared with the control drug and were found to possess either similar or increased activities. A previous research study has reported the antibacterial activity of whole plant extract of Aerva lanata against both multi-drug resistant (Escherichia coli and Pseudomonas aeruginosa which are extended spectrum beta lactamase (ESBL) producers) and common human pathogens (Salmonella typhi, Salmonella paratyphi A, Salmonella paratyphi B, Proteus spp, Streptococcus spp, Klebsiella spp, Serretia marcescens, Escherichia coli and Pseudomonas aeruginosa). The study revealed that ethanolic extract showed maximum zone of inhibition against Klebsiella pneumoniae, Proteus mirabilis and Pseudomonas aeruginosa (ESBL). It was also observed that ethanolic extract was ineffective against Salmonella paratyphi A. The study results also indicated that petroleum ether and benzene plant extracts were ineffective against many other bacterial species [26].

The current study results reveal an increased activity of the ethanolic and the chloroform extracts of Aerva lanata against Klebsiella pneumoniae, as compared to the same concentration of the standard drug tested. The results also clearly demonstrate a considerable decrease in the activities of most Aerva lanata extracts against gram poistive bacteria including the Staphylococcus aureus, Streptococcus pyogenes, and Enterococcus faecalis. The antifungal activities of the Aerva lanata plant extracts were similar to the standard drug tested and has shown activity against both the yeasts (Candida albicans) and the filamentous fungi (Fusarium oxysporum, Drechslera halodes, and Colletotrichum falcatum). The acetone solvent extracts showed least antimicroboial activities against both bacteria and the fungi as compared to the standard antibiotic tested.

Similar to our study, a previous report highlighted the antimicrobial properties of ethyl acetate, and methanolic extract of Aerva lanata plant. Thus, it can be confirmed that irrespective of the solvent used, Aerva lanata plant extracts have a great potential to be future candidates as antimicrobial agents [27].
Results of a previous study which tested the plant extract of Aerva lanata against bacteria like Staphylococcus saprophyticus, Streptococcus agalactiae, Acinetobacter baumannii, Xanthomonas citri, Klebsiella pneumoniae, and Proteus vulgaris, revealed that the root extracts were demonstrating increased antibacterial activities as compared to the flower extracts [28].

\section{Conclusion}

Antibacterial and antifungal activities of the plant extracts of Aerva lanata were found to be effective against both bacteria and fungi as observed by the study results. The Aerva lanata plant extracts were more effective against gram negative bacteria as against grampositive bacteria. Only few studies are available in literatures which have evaluated the in-vitro and the potential in-vivo antimicrobial activities of various plants extracts of Aerva lanata. In view of emerging multidrug resistance among various microbes isolated from human infections, extensive research on the potential antimicrobial properties of Aerva lanata plant extracts is warranted. Further studies including the proven multidrug resistant microorganisms and their susceptibility to different plant extract both in-vitro and in-vivo is the need of the hour.

\section{References}

[1] Amujoyegbe OO, Idu M, Agbedahunsi JM, Erhabor JO. Ethnomedicinal survey of medicinal plants used in the management of sickle cell disorder in Southern Nigeria. J Ethnopharmacol. 2016 , 185: 347-60.

[2] Hubick S, Jayaraman A, McKeen A, et al. A potent synthetic inorganic antibiotic with activity against drug-resistant pathogens. Scientific Reports. 2017, 7:41999.

[3] Kandi V, Kandi S. Antimicrobial properties of nanomolecules: potential candidates as antibiotics in the era of multi-drug resistance. Epidemiology and Health. 2015, 37:e2015020.

[4] Goyal M, Pareek A, Nagori BP, Sasmal D. Aerva lanata: A review on phytochemistry and pharmacological aspects. Pharmacognosy Reviews. 2011, 5:195-198.

[5] U.S. National Plant Germplasm System. (2009). Accessed: March 19, 2017: https://npgsweb.arsgrin.gov/gringlobal/taxonomydetail.aspx?101478.

[6] Yuldashev AA, Yuldashev MP, Abdullabekova VN. Components of Aerva lanata. Chem Nat Comp. 2002, 38: 293-4.

[7] Vetrichelvan T, Jegadeesan M, Palaniappan MS, Murali NP, Sasikumar K. Diuretic and anti-inflammatory activities of Aerva lanata in rats. Ind J Pharam Sci. 2000, 62: 300-302.

[8] Mandal B, Swati M. Aerva lanata: A blessing of Mother Nature. J Pharmacogn Phytochem. 2016, 5: 92-101.

[9] Ramalingam V, Rajangam U. Hypoglycemic and hypolipidemic effects of Aerva lanata (Linn.) on alloxan induced diabetic rats. Journal of Applied Biology \& Biotechnology. 2016, 4:048-056.

[10] Soundararajan P, Mahesh R, Ramesh T, Begum VH: Effect of Aerva lanata on calcium oxalate urolithiasis in rats. Indian J Exp Biol. 2006, 44: 981-6.

[11] Ramana KV, Vikram G: Aerva Lanata (L.) Juss. ex Schult.: a Potentially Useful Medicinal Plant. Medicinal Plant Research. 2015, 5: 1-4.

[12] Vedavathy S, Rao KN: NEPHROPROTECTORS- FOLK MEDICINE OF RAYALASEEMA ANDRA PRADESH. Ancient Science of Life. 1990, 9: 164-167.

[13] Rajesh R, Chitra K, Padmaa MP: Aerva lanata (Linn.) Juss. ex Schult.-An overview. Indian Journal of Natural Products and Resources. 2011, 2: 5-9. 
[14] Pandikumar P, Chellappandian M, Mutheeswaran S, Ignacimuthu S: Consensus of local knowledge on medicinal plants among traditional healers in Mayiladumparai block of Theni District, Tamil Nadu, India. J Ethnopharmacol. 2011, 134: 354-62.

[15] Chowdhury D, Sayeed A, Islam A, Shah Alam Bhuiyan M, Astaq Mohal Khan GR: Antimicrobial activity and cytotoxicity of Aerva lanata. Fitoterapia. 2002, 73: 92-4.

[16] Kaushik NK, Bagavan A, Rahuman AA, et al: Evaluation of antiplasmodial activity of medicinal plants from North Indian Buchpora and South Indian Eastern Ghats. Malaria Journal. 2015, 14: 65.

[17] Abou-Zeid AM, Altalhi AD, Abd El-Fattah RI: Fungal control of pathogenic fungi isolated from wild plants in Taif Governorate, Saudia Arabia. Roum Arch Microbiol Immunol. 2007, 66: 90-6.

[18] Baronets NG, Adlova GP, Mel'nikova VA: [Effect of medicinal plant extracts on the growth of microorganisms]. Zh Mikrobiol Epidemiol Immunobiol. 2001, 5: 71-2.

[19] Duraipandiyan V, Ayyanar M, Ignacimuthu S: Antimicrobial activity of some ethnomedicinal plants used by Paliyar tribe from Tamil Nadu, India. BMC Complement Altern Med. 2006, 6: 35.

[20] Clinical and Laboratory Standards Institute (CLSI). Performance Standards for Antimicrobial Disk Susceptibility Tests; Approved Standard-Eleventh Edition. CLSI document M02-A11. Clinical and Laboratory Standards Institute, 950 West Valley Road, Suite 2500, Wayne, Pennsylvania 19087 USA, 2012.

[21] Madugula P, Reddy S, Koneru J, Rao AS, Sruthi R, Dalli DT: "Rhetoric to Reality"- Efficacy of Punica Granatum Peel Extract on Oral Candidiasis: An in vitro Study. J Clin Diagn Res. 2017, 11:ZC114-ZC117.

[22] Bauer AW, Kirby WM, Sherris JC, Turck M: Antibiotic susceptibility testing by a standardized single disk method. Am J Clin Pathol. 1966, 45:493-6.

[23] Method for antifungal disk diffusion susceptibility testing of yeasts. (2009). Accessed: March 19, 2017: http://shop.clsi.org/site/Sample_pdf/M44A2_sample.pdf.

[24] Chawla P, Chawla A, Vasudeva N, Sharma SK: A review of chemistry and biological activities of the genus Aerva--a desert plant. Acta Pol Pharm. 2012, 69:171-7.

[25] Aerva lanata (L.) Juss. ex Schult.. [online] India Biodiversity Portal,Species Page: Available at: http://indiabiodiversity.org/biodiv/species/show/32892 [Accessed date Jun 19, 2017].

[26] Manickam Murugan, Veerabahu Ramasamy Mohan. Phytochemical, FT-IR and antibacterial activity of whole plant extract of Aerva lanata (L.) Juss. Ex. Schult. Journal of Medicinal Plants Studies. 2014, 2: 51-57.

[27] Chowdhury D, Sayeed A, Islam A, Shah Alam Bhuiyan M, Astaq Mohal Khan GR. Antimicrobial activity and cytotoxicity of Aerva lanata. Fitoterapia. 2002 Feb; 73(1): 92-4.

[28] Manickam Murugan, Veerabahu Ramasamy Mohan. Phytochemical, FT-IR and antibacterial activity of whole plant extract of Aerva lanata (L.) Juss. Ex. Schult. Journal of Medicinal Plants Studies. 2014; 4(3): 51-57. 